\title{
PEMANFAATAN JARINGAN SARAF TIRUAN PROPAGASI BALIK UNTUK MODEL PREDIKSI DERET WAKTU PASANG SURUT
}

\section{THE USE OF BACKPROPAGATION NEURAL NETWORK FOR TIME SERIES TIDE-LEVEL PREDICTION MODEL}

\author{
Afif Widaryanto ${ }^{*}$ dan Fineza Ilova ${ }^{1}$ \\ ${ }^{1}$ Balai Teknologi Survei Kelautan, Badan Pengkajian dan Penerapan Teknologi (BPPT), \\ Jl. MH. Thamrin No. 8, Jakarta \\ *E-mail: afif.widaryanto@bppt.go.id
}

\begin{abstract}
ABSTRAK
Kebanyakan aktifitas yang berkaitan dengan laut sangat memerlukan data prediksi pasang surut. Hal ini menuntut adanya sistem prediksi dengan akurasi yang tinggi. Penerapan kecerdasan artifisial yang semakin meluas dengan berbagai keandalannya menginspirasi penelitian ini untuk mengaplikasikan model prediksi pasang surut menggunakan jaringan saraf tiruan. Dengan masukan data pasang surut tujuh hari sebelumnya untuk memprediksi pasang surut 6 dan 12 jam ke depan dapat modelkan menggunakan jaringan sarat tiruan berbasis metode pembelajaran propagasi balik. Hasilnya, unjuk kerja pengujian model prediksi sangat memuaskan dengan ratarata akurasi di atas $90 \%$ serta nilai MSSE(mean sum square error) yang rendah.
\end{abstract}

Kata Kunci: pasang surut; kecerdasan artifisial; jaringan saraf tiruan; model prediksi

\section{ABSTRACT}

[The Use of Backpropagation Neural Network for Time Series Tide-Level Prediction Model] Most of ocean related activities require tidal prediction data. This requires a prediction system with high accuracy. The widespread application of artificial intelligence with its various reliability inspired this research to apply tidal prediction models using artificial neural networks. With the input of tidal data for the previous seven days to predict the tide for the next 6 and 12 hours, it can be modeled using an artificial network based on back propagation learning method. As a result, the performance of the prediction model testing is very satisfying with an average accuracy of above $90 \%$ and low MSSE (mean sum square error) values.

Keywords: tide; artificial intelligent; neural network; prediction model

\section{PENDAhuluan}

Prediksi pasut yang akurat merupakan masalah penting untuk kegiatan konstruksi di daerah muara sungai, pesisir dan lepas pantai. Data pasang surut juga penting untuk pembangunan dermaga, pelabuhan dan keperluan navigasi. Aktifitas di daerah lepas pantai sangat memerlukan data pasang surut yang akurat demi keamanan dan kelancaran sebuah operasi seperti pemasangan platform, navigasi, bongkar muat di area zona pasang tinggi. Metode prediksi pasang surut telah banyak dikembangkan. Sebagai contoh, algoritma kalman filter dapat diaplikasikan untuk prediksi pasang surut jangka pendek (Yen et al., 1996).

Jaringan saraf tiruan telah diaplikasikan secara luas di berbagai bidang, seperti identifikasi sistem nonlinear, prediksi dan estimasi numerik. Belakangan ini jaringan saraf tiruan telah diaplikasikan untuk prediksi fenomena alam. Dalam sebuah studi, jaringan saraf tiruan telah diaplikasikan untuk memprediksi fenomena deret waktu multivariasi dengan kinerja yang lebih baik dari model ARMA(Chakraborty et.al., 
1992). Jaringan saraf tiruan juga digunakan untuk memprediksi level air sungai(Konda T. et al., 1995). Studi lain menunjukkan bahwa jaringan Feed-Forward Back Propagation (FFBP) dengan algoritma Levenberg-Marquardt (LM) memberikan korelasi yang baik dibandingkan dengan algoritma lain dalam memprediksi pasang surut (Meena, et al., 2015).

Studi kali ini mengaplikasikan jaringan saraf tiruan dengan struktur jumlah neuron keluaran lebih dari satu, yaitu untuk memprediksi level pasang surut pada waktu-waktu yang datang sesuai dengan periode waktu data. Algoritma pembelajaran yang digunakan adalah propagasi balik untuk memperbaiki nilai bobot pada masing-masing jaringan sebagai respon dari besarnya nilai kesalahan pada setiap iterasinya. Keterbatasan data observasi menyebabkan pemanfaatan data prediksi sebagai data set yang diunduh dari sistem prediksi milik Badan Informasi Geospasial. Namun hal ini tidak mengurangi tujuan studi untuk membuat model prediksi pasang surut.

Data set diambil dari empat lokasi yang berbeda dari beberapa wilayah di Indonesia untuk menguji karakteristik masing-masing model. Masing-masing lokasi dibuat struktur model jaringan saraf tiruan dengan pembelajaran independent.

\section{METODOLOGI}

Jaringan saraf tiruan merupakan teknik mengelola informasi yang berbasis komputasi dari sebuah matematika model yang didasari dari neuron pada jaringan saraf pada otak manusia. Tujuan dari jaringan saraf tiruan adalah meniru cara kerja suatu sistem yang kompleks dan sangat sulit untuk dimodelkan jika dengan persamaan matematis, sistem yang sulit untuk dimodelkan biasanya adalah sistem yang berupa non-linear. Jaringan saraf tiruan didesain untuk dapat meniru cara kerja sisten non-linear tersebut secara otomatis melalui metode pembelajaran tertentu. Pembelajaran ini bertujuan untuk mengatur nilai-nilai bobot pada hubungan antar neuron menjadi bervariasi. Nilai-nilai bobot yang bervariasi ini yang membuat jaringan saraf tiruan memiliki sifat yang unik dan kompleks., sehingga mampu meniru cara kerja sistem yang kompleks tanpa dibutuhkannya persamaan matematis. Oleh karenanya, dalam jaringan saraf tiruan, bobot dapat dikatakan sebagai salah satu bagian terpenting dari jaringan saraf tiruan. Selain bobot, elemen yang juga penting pada jaringan saraf tiruan adalah fungsi aktivasi. Fungsi aktivasi adalah fungsi matematis yang berlaku pada neuron Hidden dan neuron Output. Fungsi ini meniru cara kerja firing sel-sel neuron otak, dimana setelah melewati suatu nilai tertentu maka neuron baru mengirimkan sinyal ke neuron-neuron berikutnya.

Pada setiap neuron terdapat dua operasi matematika berbeda. Operasi matematika pertama dari lapisan ini dinyatakan sebagai total dari perkalian masing-masing neuron dari lapisan masukan dengan koneksi bobot yang sesuai kemudian ditambahkan dengan suatu bias, seperti tertulis pada persamaan 2.1. Notasi Yin adalah hasil propagasi W, yaitu vektor atau matriks berisikan nilai bobot, Wi adalah nilai bobot pada neuron ke-i, $\mathrm{X}$ adalah vektor dari nilai neuron masukan dan Xi adalah nilai neuron ke-i dari lapisan masukan, dan $\mathrm{b}$ adalah bias.

$$
f(x)=y_{\text {in }}=\sum_{i} w_{i} x_{i}+b=w * x+w_{\text {bias }}
$$

Operasi kedua adalah operasi yang membuat jaringan saraf tiruan memiliki kemampuan menangkap sifat non-linearitas, yaitu fungsi aktivasi. Pada penelitian ini digunakan fungsi aktivasi sigmoid sesuai persamaan 2.2. 


$$
f\left(y_{i n}\right)=y=\frac{1-e^{-z}}{1+e^{-z}}
$$

Fungsi ini memiliki nilai akhir antara -1 hingga 1 . Nilai yang dimasukkan pada fungsi aktivasi adalah nilai akumulasi yang telah dihitung sebelumnya, dalam hal ini nilai dinotasikan Yin untuk menghasilkan Y yang berarti keluaran neuron.

Pada struktur jaringan saraf tiruan MLP(multi layer perceptron) yang terdiri dari beberapa neuron pada lapisan masukan, lapisan tersembunyi dan lapisan keluaran, maka persamaan (2.1) dan (2..2) masing-masing terjadi pada lapisan tersembunyi $(Z)$ dan lapisan keluaran (Y). Notasi $\mathrm{Z}$ _in adalah hasil propagasi neuron masukan $\mathrm{X}$ yang dikalikan dengan bobot $\mathrm{V}$ dan menjadi nilai masukan untuk neuron tersembunyi dan $\mathrm{Z}$ adalah keluaran neuron tersembunyi setelah melalui fungsi aktivasi. Sedangkan notasi $\mathrm{Y}$ _in adalah hasil propagasi neuron tersembunyi $\mathrm{Z}$ yang dikalikan dengan bobot $\mathrm{W}$ dan menjadi nilai masukan untuk neuron keluaran dan $\mathrm{Y}$ adalah keluaran neuron keluaran setelah melalui fungsi aktivasi.

Perhitungan error dilakukan untuk mengetahui performa sistem berdasarkan hasil estimasi (Y) dengan nilai target (t). Error dihitung menggunakan fungsi-fungsi tertentu yang menyatakan seberapa besar kesalahan dari sistem. Pada penelitian ini digunakan fungsi perhitungan error rata-rata jumlah kesalahan kuadrat (MSSE - Mean Sum Squared Error) dengan persamaan sebagai berikut:

$$
I=\frac{1}{N} \sum_{i=1}^{N} \frac{1}{2}\left(t_{i}-Y\right)^{2}
$$

Propagasi balik adalah sebuah metode pembelajaran untuk mengoreksi nilai bobot berdasarkan perhitungan error. Maka diperlukan perhitungan untuk mendapatkan turunan error terhadap neuron lapisan tersebut sebelum fungsi aktivasi pada lapisan keluaran $\left(\partial_{J} / \partial_{Y_{-} i n}\right)$, turunan error terhadap bobot yang memasuki lapisan keluaran $\left(\partial_{J} / \partial_{W}\right)$, turunan error terhadap neuron lapisan tersebut sebelum fungsi aktivasi pada lapisan tersembunyi $\left(\partial_{J} / \partial_{z_{i} \text { in }}\right)$; serta turunan error terhadap bobot yang memasuki lapisan tersembunyi $\left(\partial_{J} / \partial_{V}\right)$. Nilai turunan error terhadap fungsi aktivasi lapisan keluaran $\left(\partial_{J} / \partial_{Y_{-} \text {in }}\right)$ dapat dijabarkan menjadi persamaan seperti berikut:

$$
\frac{\partial j}{\partial Y_{-} i n}=\frac{\partial j}{\partial Y} \frac{\partial Y}{\partial Y_{-} i n}=(t-Y) f^{\prime}\left(Y_{-} i n\right)
$$

Dengan memasukkan persamaan untuk mencari nilai error $(\mathbf{J})$ pada persamaan (2.3) dan perhitungan pada neuron lapisan keluaran Y maka didapatkan persamaan (2.5)

Dengan:

$$
\frac{\partial j}{\partial Y_{-} i n}=\frac{\partial \frac{1}{2}(t-Y)^{2}}{\partial Y} \frac{\partial f\left(Y_{i n}\right)}{\partial Y_{-} i n}=(t-Y) f^{\prime}\left(Y_{-} i n\right)
$$

$$
f^{\prime}\left(Y_{\text {in }}\right)=0.5(1+Y)(1-Y)
$$


Selanjutnya dicari turunan terhadap bobot yang memasuki lapisan keluaran $\left(\partial_{J} / \partial_{W}\right)$ dapat dijabarkan menjadi persamaan berikut:

$$
\frac{\partial j}{\partial W}=\frac{\partial j}{\partial Y} \frac{\partial Y}{\partial Y_{-} i n} \frac{\partial Y_{-} i n}{\partial W}
$$

Dengan memasukkan persamaan $\left(\partial_{J} / \partial_{Y_{-} i n}\right)$ yang telah didapatkan pada persamaan (2.5) dan persamaan untuk mencari nilai Y_in maka didapatkan persamaan:

$$
\begin{aligned}
\frac{\partial j}{\partial W} & =\frac{\partial j}{\partial Y_{-} i n} \frac{\partial Y_{-} i n}{\partial W}=(t-Y) f^{\prime}\left(Y_{-} i n\right) \frac{\partial\left(W_{\text {bias }}+W * Z\right)}{\partial W} \\
\frac{\partial j}{\partial W} & =(t-Y) f^{\prime}\left(Y_{-} i n\right) Z
\end{aligned}
$$

Kemudian nilai turunan error terhadap fungsi aktivasi lapisan tersembunyi $\left(\partial_{J} / \partial_{z_{-} i n}\right)$ dapat dijabarkan menjadi persamaan seperti berikut:

$$
\frac{\partial j}{\partial Z_{-} i n}=\frac{\partial j}{\partial Y} \frac{\partial Y}{\partial Y_{-} i n} \frac{\partial Y_{-} i n}{\partial Z} \frac{\partial Z}{\partial Z_{-} i n}
$$

Dengan memasukkan persamaan $\left(\partial_{J} / \partial_{z_{-} \text {in }}\right)$ yang telah didapatkan pada persamaan

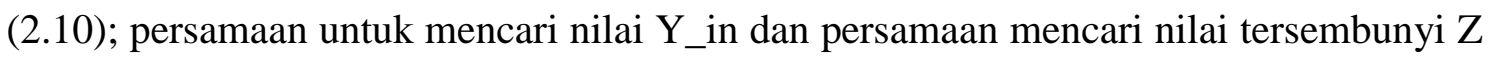
maka didapatkan persamaan:

$$
\begin{aligned}
\frac{\partial j}{\partial Z_{-} i n} & =\frac{\partial j}{\partial Y_{-} i n} \frac{\partial Y_{-} i n}{\partial Z} \frac{\partial Z}{\partial Z_{-} i n} \\
\frac{\partial j}{\partial Z_{-} i n} & =(t-Y) f^{\prime}\left(Y_{-} i n\right) \frac{\partial\left(W_{\text {bias }}+W * Z\right)}{\partial Z} \frac{\partial f\left(Z_{\text {in }}\right)}{\partial Z_{\text {in }}} \\
\frac{\partial j}{\partial Z_{-} i n} & =(t-Y) f^{\prime}\left(Y_{\text {in }}\right) W f^{\prime}\left(Z_{\text {in }}\right)
\end{aligned}
$$

Dengan

$$
f^{\prime}\left(Z_{i n}\right)=0.5(1+Z)(1-Z)
$$

Selanjutnya dicari turunan terhadap bobot yang memasuki lapisan tersembunyi $\left(\partial_{J} / \partial_{V}\right)$ dapat dijabarkan menjadi persamaan berikut.

$$
\frac{\partial j}{\partial V}=\frac{\partial j}{\partial Y} \frac{\partial Y}{\partial Y_{-} i n} \frac{\partial Y_{-} i n}{\partial Z} \frac{\partial Z}{\partial Z_{-} i n} \frac{\partial Z_{-} i n}{\partial V}
$$

Dengan memasukkan persamaan $\left(\partial_{J} / \partial_{z_{-} \text {in }}\right)$ yang telah didapatkan pada persamaan (2.13) dan persamaan untuk Z_in maka didapatkan persamaan

$$
\frac{\partial j}{\partial V}=\frac{\partial j}{\partial Z_{-} i n} \frac{\partial Z_{-} i n}{\partial V}=(t-Y) f^{\prime}\left(Y_{-} i n\right) W f^{\prime}\left(Z_{-} i n\right) \frac{\partial\left(V_{b i a s}+V * X\right)}{\partial V}
$$




$$
\frac{\partial j}{\partial V}=(t-Y) f^{\prime}\left(Y_{-} i n\right) W f^{\prime}\left(Z_{-} i n\right) X
$$

Pembaruan bobot dilakukan setelah nilai turunan fungsi kesalahan terhadap bobot dihitung.

$$
\begin{aligned}
& \Delta W_{\text {baru }}=\alpha \frac{\partial j}{\partial Y_{-} \text {in }} Z+\mu \Delta W_{\text {lama }} \\
& \Delta V_{\text {baru }}=\alpha \frac{\partial j}{\partial Z_{-} \text {in }} X+\mu \Delta V_{\text {lama }}
\end{aligned}
$$

Persamaan (2.18) menyatakan besar nilai perubahan bobot yang menghubungkan neuron-neuron pada lapisan tersembunyi dengan neuron-neuron pada lapisan keluaran. Persamaan (2.19) menyatakan besar nilai perubahan bobot yang menghubungkan neuron-neuron pada lapisan masukan dengan neuron-neuron pada lapisan tersembunyi. Dengan, ${ }^{\alpha}$ adalah laju pembelajaran dan ${ }^{\mu}$ dinyatakan sebagai momentum.

Keterbatasan ketersediaan data observasi yang cukup pajang, maka pada kajian ini menggunakan data pasang surut prediksi tahun 2019 (Tabel 1, Gambar 1) yang diunduh dari laman Badan Informasi Geospasial (http://tides.big.go.id/pasut/index.html) sebagai data set dengan interval data 1 jam sehingga terdapat 8760 data. Untuk data pelatihan digunakan 1000 data pertama dan selebihnya untuk data pengujian.

Tabel 1. Data Prediksi Pasang Surut Tahun 2019 (data set).

\begin{tabular}{lll}
\hline Lokasi & Koordinat Lintang & Koordinat Bujur \\
\hline Lokasi \#1 & $6^{\circ} 5^{\prime} 43.239^{\prime \prime} \mathrm{LS}$ & $106^{\circ} 48^{\prime} 0.450^{\prime \prime} \mathrm{BT}$ \\
Lokasi \#2 & $7^{\circ} 46^{\prime} 57.842^{\prime \prime} \mathrm{LS}$ & $109^{\circ} 2^{\prime} 45.690^{\prime \prime} \mathrm{BT}$ \\
Lokasi \#3 & $4^{\circ} 10^{\prime} 12.263^{\prime \prime} \mathrm{LS}$ & $114^{\circ} 37^{\prime} 44.011^{\prime \prime} \mathrm{BT}$ \\
Lokasi \#4 & $5^{\circ} 19^{\prime} 1.369^{\prime \prime} \mathrm{LS}$ & $19^{\circ} 21^{\prime} 44.298^{\prime} \mathrm{BT}$ \\
\hline
\end{tabular}

Batasan kajian ini adalah untuk memodelkan prediksi deret waktu pasang surut dengan masukan data selama satu pekan atau 168 jam dan keluaran prediksi 6 jam dan 12 jam ke depan. Oleh karena itu struktur jaringan saraf tiruannya terdiri dari 168 neuron masukan dan 6 neuron keluaran untuk prediksi 6 jam ke depan dan 12 neuron keluaran untuk prediksi 12 jam keluaran. Di antara neuron masukan dan neuron keluaran terdapat satu lapisan neuron tersembunyi dengan jumlah 168 neuron. 


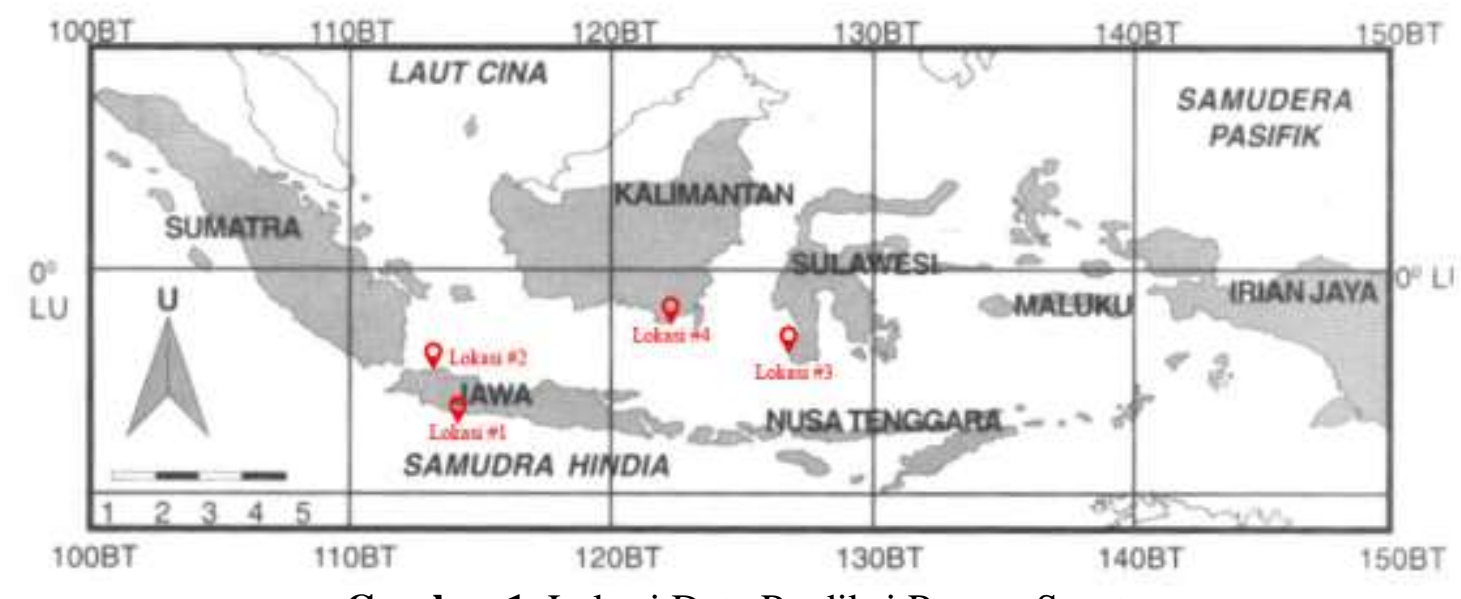

Gambar 1. Lokasi Data Prediksi Pasang Surut

Jika neuron masukan dinotasikan dengan $\mathrm{x}(\mathrm{k}), \mathrm{x}(\mathrm{k}-1), \mathrm{x}(\mathrm{k}-2), \ldots, \mathrm{x}(\mathrm{k}-\mathrm{n})$ dan keluaran $\mathrm{y}(\mathrm{k}+1), \mathrm{y}(\mathrm{k}+2), \ldots, \mathrm{y}(\mathrm{k}+\mathrm{m})$ serta hasil prediksi $\hat{\mathrm{y}}(\mathrm{k}+1), \hat{\mathrm{y}}(\mathrm{k}+2), \ldots, \hat{\mathrm{y}}(\mathrm{k}+\mathrm{m})$ dengan jumlah masukan $\mathrm{n}$ dan keluaran $\mathrm{m}$, maka struktur pembelajaran jaringan saraf tiruan dapat diperlihatkan Gambar 2.

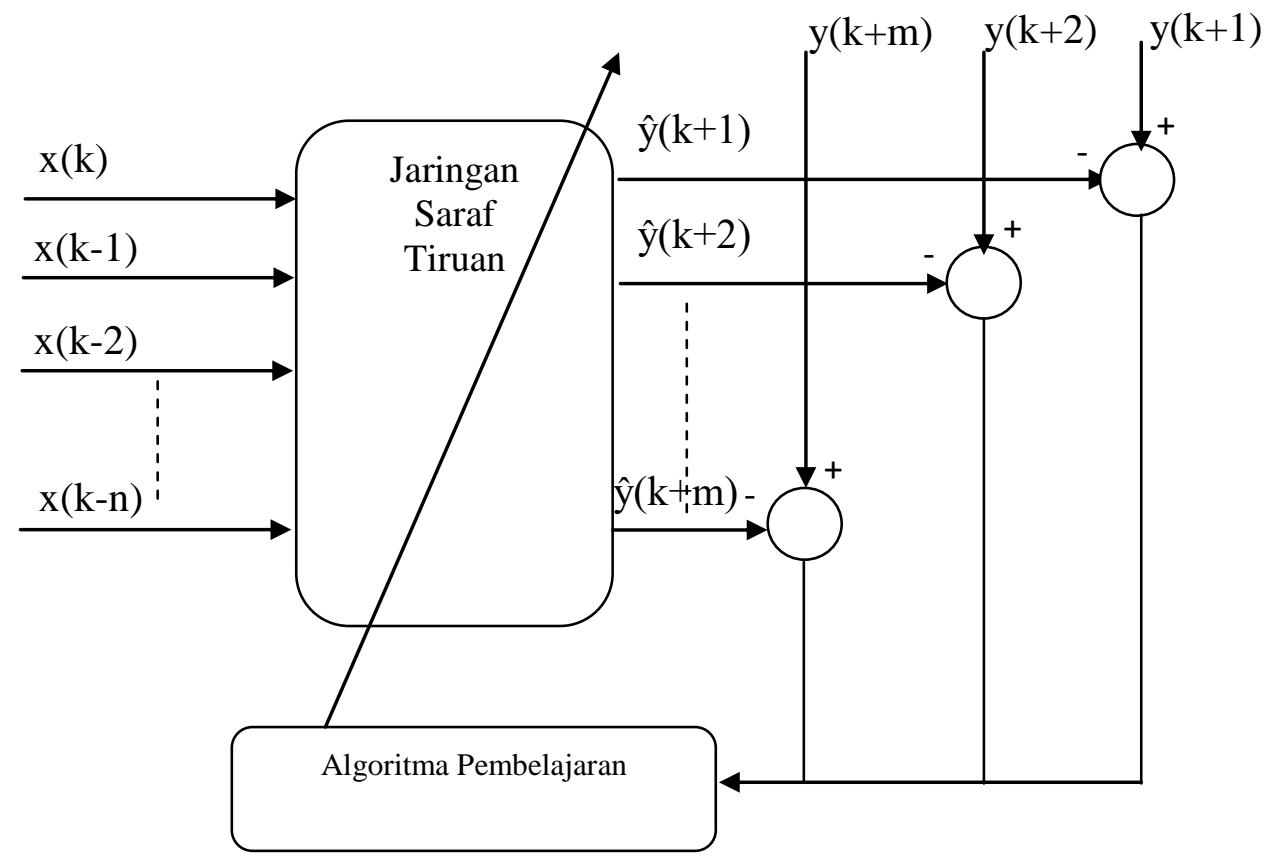

Gambar 2. Struktur Pembelajaran Jaringan Saraf Tiruan.

\section{HASIL DAN PEMBAHASAN}

Pemodelan prediksi terlebih dahulu dilakukan dengan proses pembelajaran dengan jumlah iterasi tertentu atau target nilai minimal error yang harapkan. Kemudian dilakukan verifikasi atau pengujian untuk mengetahui tingkat keberhasilan model prediksi tersebut. Tabel 2 menyajikan data proses pembelajaran model prediksi. 
Tabel 2. Pembelajaran Model Prediksi.

\begin{tabular}{lllll}
\hline \multirow{2}{*}{ Lokasi } & \multicolumn{2}{l}{ Model Prediksi 6 Jam Ke Depan } & \multicolumn{2}{l}{ Model Prediksi 12 Jam Ke Depan } \\
\cline { 2 - 5 } & Iterasi & MSSE & Iterasi & MSSE \\
\hline Lokasi \#1 & 36500 & $6.80 \times 10^{-6}$ & 31300 & $1.95 \times 10^{-6}$ \\
Lokasi \#2 & 13500 & $1.25 \times 10^{-5}$ & 21200 & $3.06 \times 10^{-5}$ \\
Lokasi \#3 & 13300 & $5.26 \times 10^{-5}$ & 21100 & $8.34 \times 10^{-5}$ \\
Lokasi \#4 & 13300 & $4.85 \times 10^{-6}$ & 21100 & $1.03 \times 10^{-5}$ \\
\hline
\end{tabular}

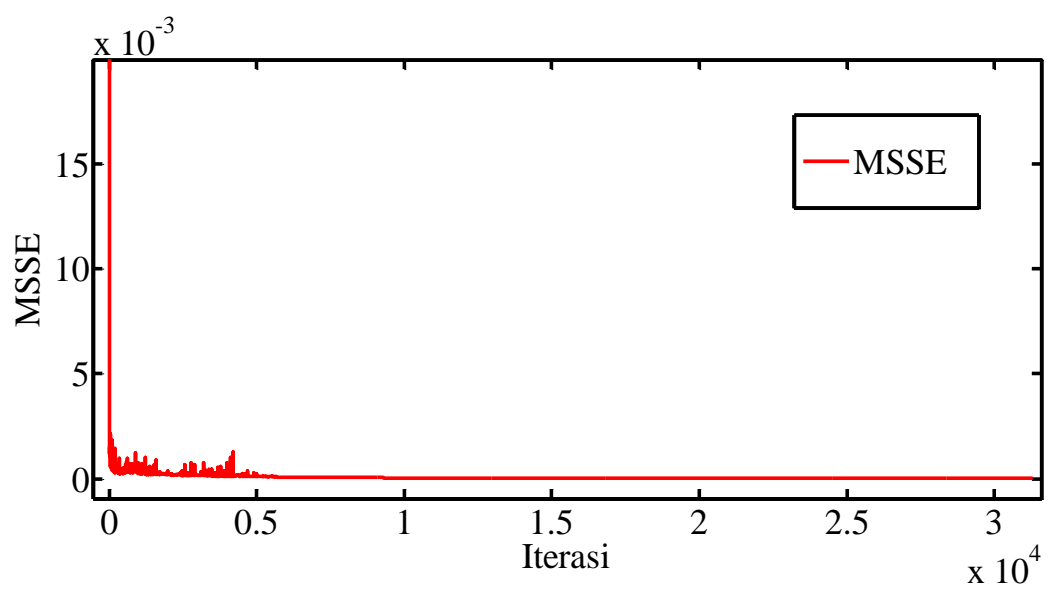

Gambar 3. MSSE Pembelajaran Model Prediksi 6 Jam Ke Depan Pada Lokasi \#1

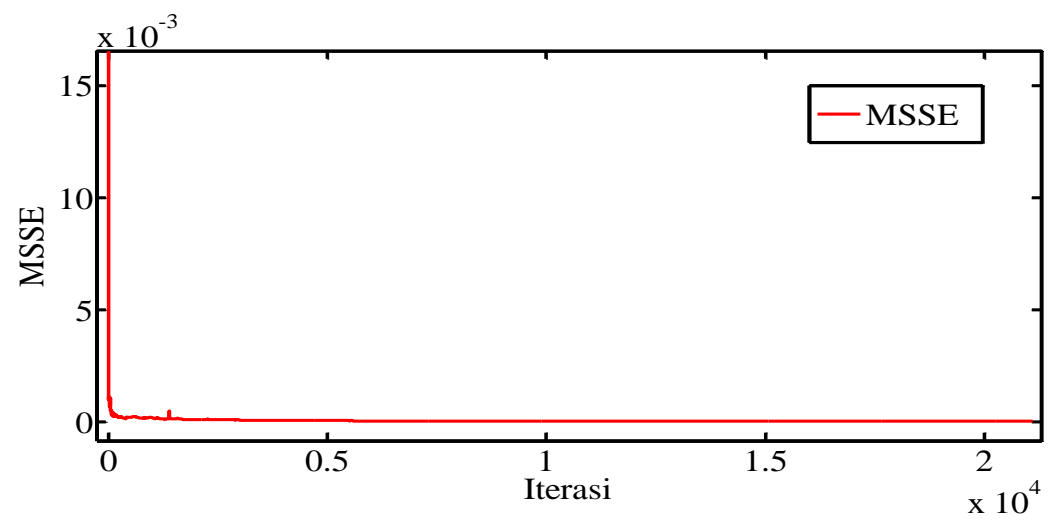

Gambar 4. MSSE Pembelajaran Model Prediksi 12 Jam Ke Depan Pada Lokasi \#4

Gambar 3 dan 4 memperlihatkan grafik penurunan nilai error (MSSE) selama pembelajaran, begitu pula terjadi pada model prediksi yang lain. Hal ini menunjukkan adanya proses pengkoreksian nilai bobot pada algoritma propagasi balik. Setiap lokasi mempunyai dua model prediksi, yaitu prediksi 6 dan 12 jam ke depan. Pembelajaran lokasi \#1 dilakukan hingga 36500 iterasi untuk model prediksi 6 jam hingga menghasilkan MSSE 6.80 x 10-6. Sedangkan untuk model prediksi 12 jam ke depan dilakukan pembelajaran 31300 iterasi hingga menghasilkan MSSE 1.95 x 10-6. Pembelajaran pada lokasi \#2, \#3, dan \#4 untuk model prediksi 6 jam ke depan masingmasing dilakukan hingga iterasi ke 13500, 13300 dan 13300 dengan MSSE akhir pada masing-masing lokasi tersebut adalah $1.25 \times 10-5,5.26$ x 10-5 dan 4.85 x 10-6. Untuk model prediksi 12 jam ke depan. lokasi \#2, \#3 dan \#4 masing-masing dilakukan hingga iterasi ke 21200, 21100 dan 21100 dengan mencapaian MSSE akhir pada masingmasing lokasi tersebut adalah $3.06 \times 10-5,8.34$ x 10-5 dan 1.03 x 10-5. Lokasi \#3 dan \#4, meskipun dilakukan dengan jumlah iterasi yang sama pada dua model prediksi 
menghasilkan MSSE yang berbeda, hal ini dikarenakan masing-masing memiliki inisialisai bobot awal yang berbeda dan karakteristik data set yang berbeda pula.

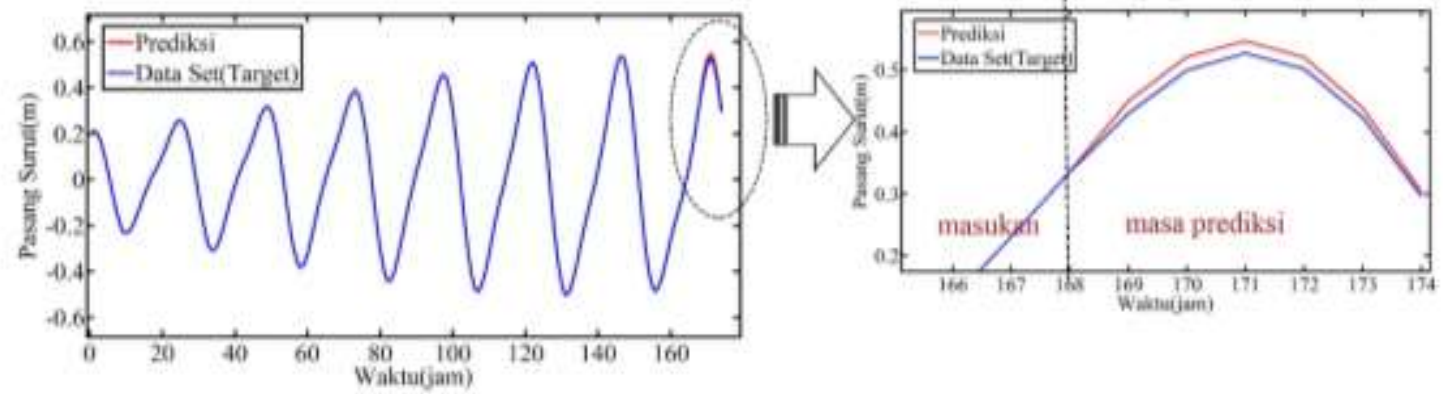

(a)

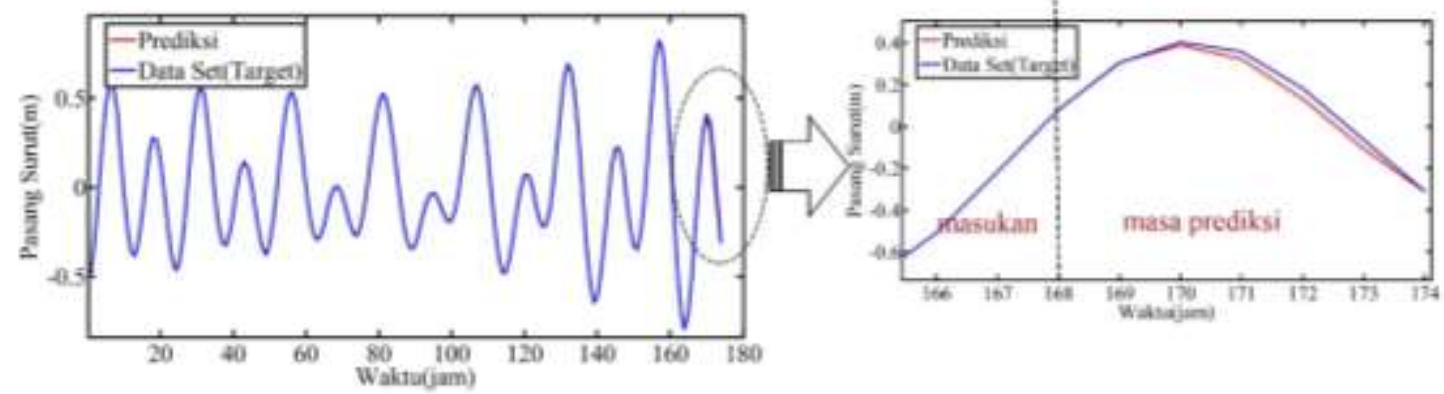

(b)

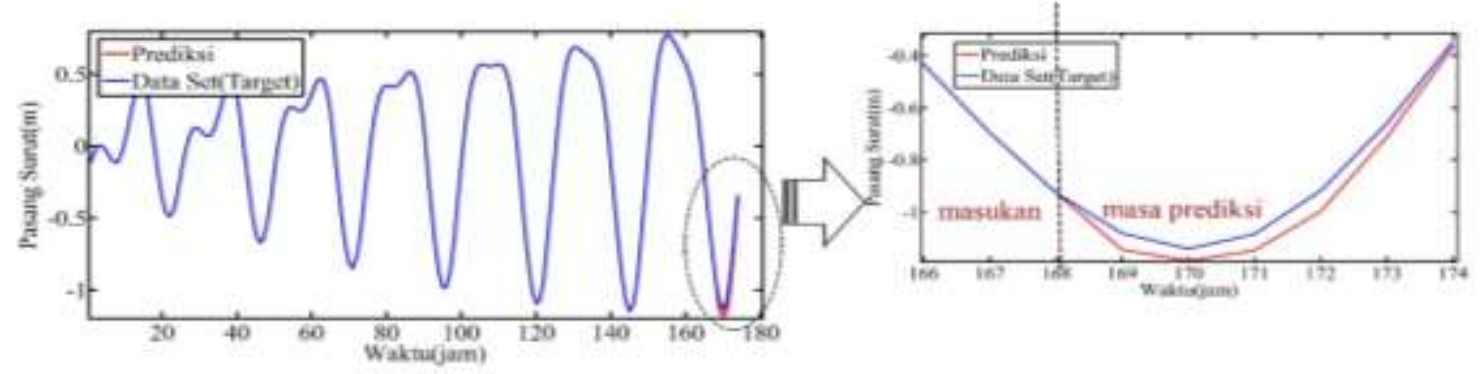

(c)

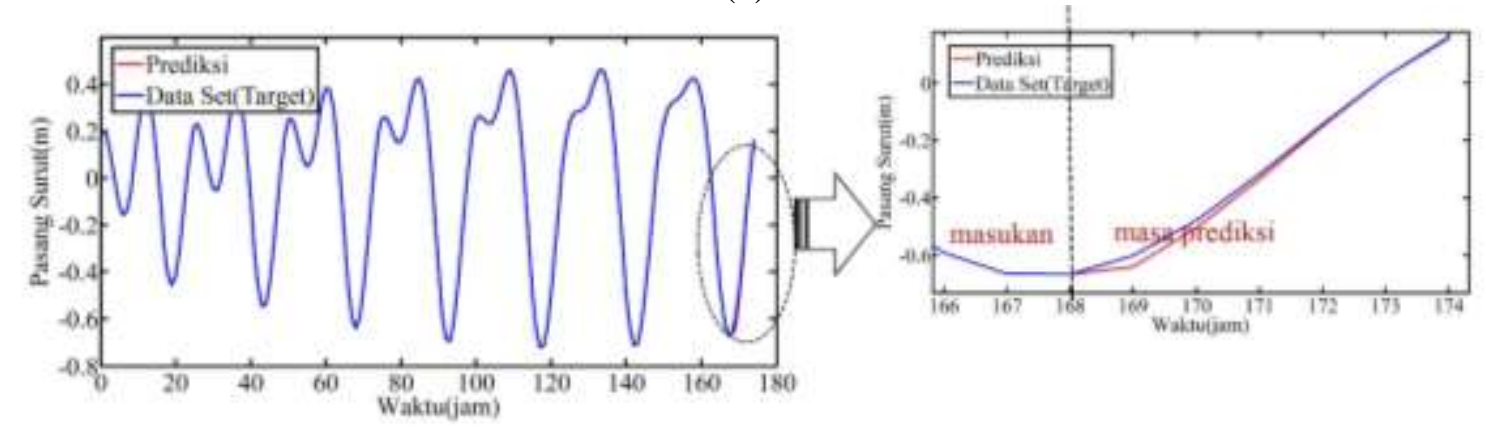

(d)

Gambar 5. Pengujian Model Prediksi 6 Jam ke Depan, (a) Lokasi \#1, (b) Lokasi \#2, (c) Lokasi \#3, (d) Lokasi \#4

Pengujian dilakukan dengan data uji, yaitu di luar data untuk pembelajaran. Hasil prediksi dibandingkan dengan target untuk mengetahui unjuk kerja model prediksi. 
Gambar 5 menunjukkan grafik hasil pengujian model prediksi 6 jam ke depan pada tiaptiap lokasi.

Data uji 174 jam diumpankan sebagai masukan 168 jam pertama, sedangkan 6 jam berikutnya digunakan untuk membandingkannya dengan hasil prediksi. Hasil uji lokasi \#1 mendapatkan MSSE 1.62 x 10-4 dengan akurasi sebesar 96.22\% dan divisualisasikan pada Gambar 3.3(a). Hasil pengujian lokasi \#2, \#3 dan \#4 masingmasing memiliki tingkat akurasi $97.08 \%, 93.74 \%$ dan $95.80 \%$ dengan perolehan MSSE $4.46 \times 10-5,1.59 \times 10-3$ dan $2.11 \times 10-4$.
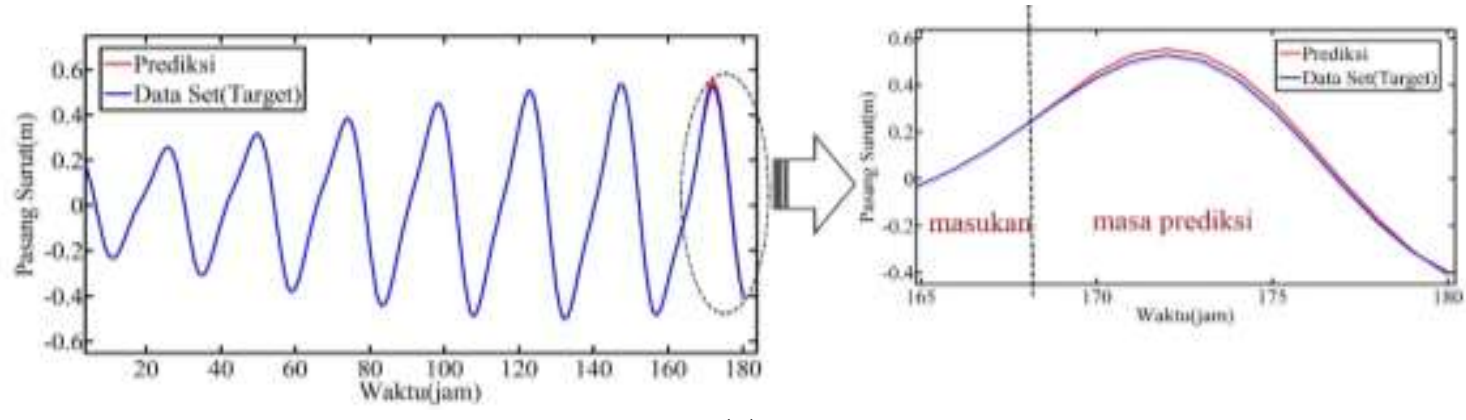

(a)

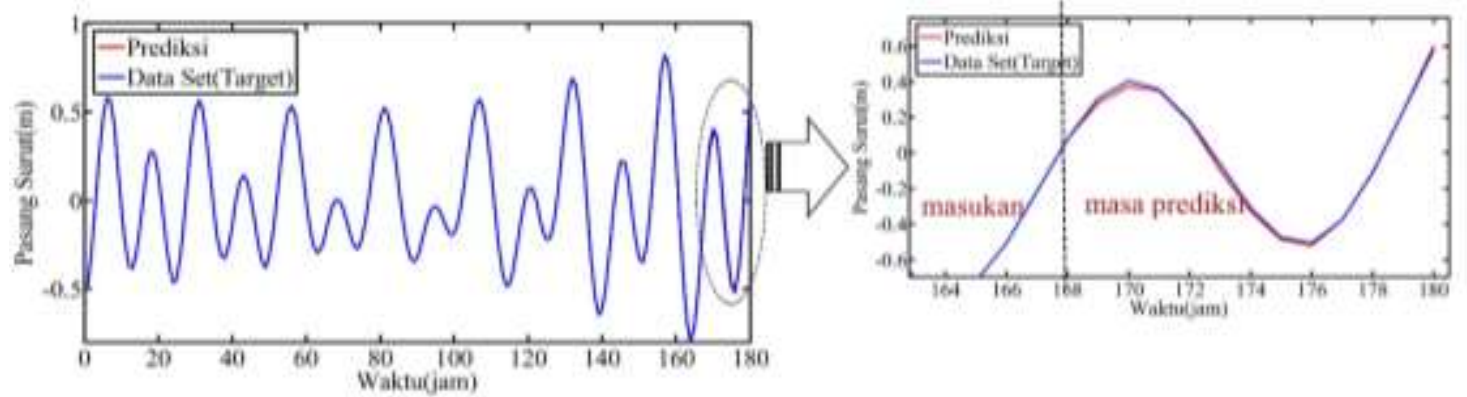

(b)
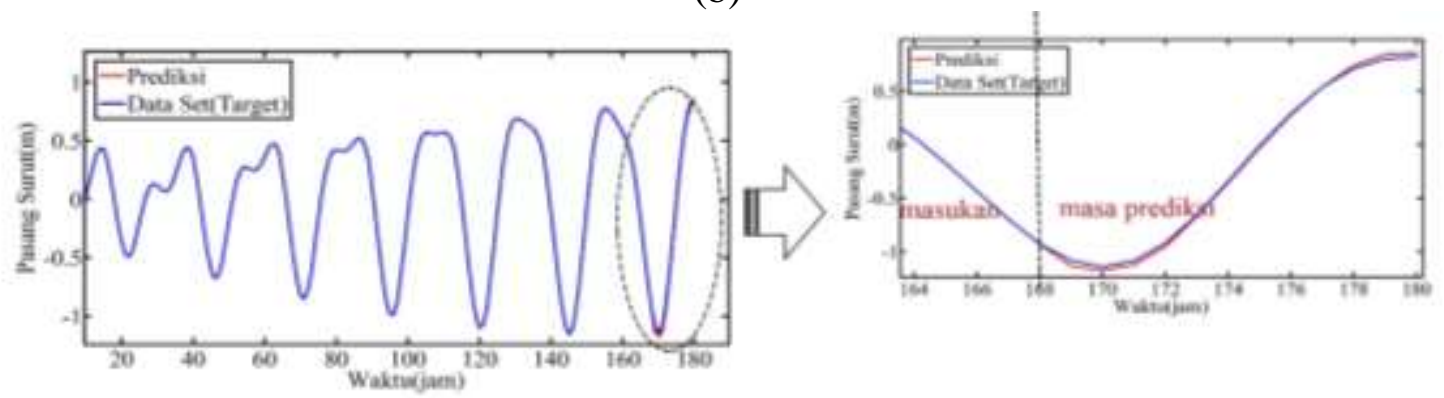

(c)

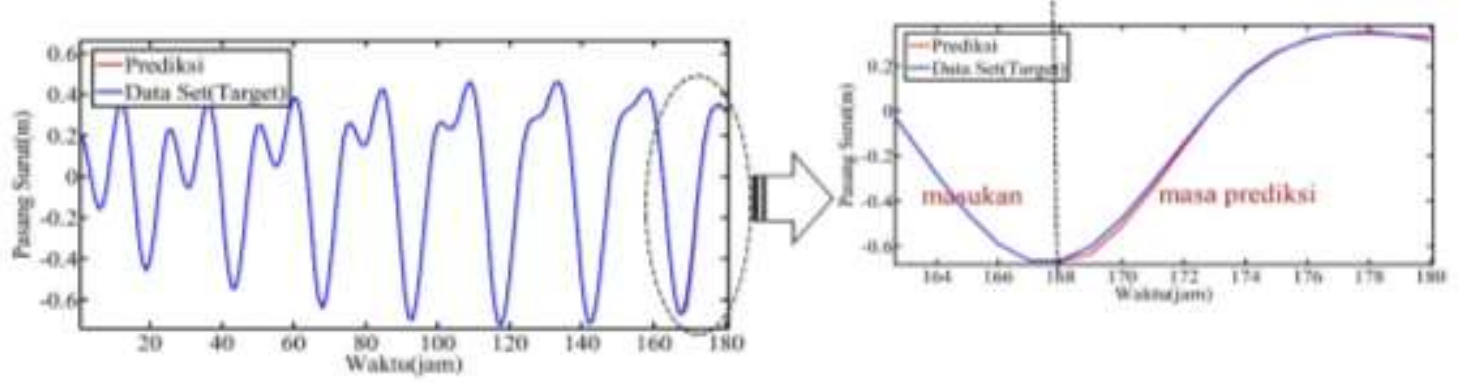

(d)

Gambar 6. Pengujian Model Prediksi 12 Jam ke Depan, (a) Lokasi \#1, (b) Lokasi \#2, (c) Lokasi \#3, (d) Lokasi \#4 
Pengujian model prediksi 12 jam ke depan menggunakan data uji 180 jam, 168 jam pertama sebagai masukan dan 12 jam berikutnya sebagai data target. Hasil 12 jam prediksi dibandingkan dengan data target untuk mengetahui unjuk kerja model seperti terlihat pada Gambar 6. Hasil uji lokasi \#1 mendapatkan MSSE 2.20 x 10-4dengan akurasi sebesar $88.96 \%$. Sementara hasil pengujian lokasi \#2, \#3 dan \#4 masing-masing memiliki tingkat akurasi $92.47 \%, 92.29 \%$ dan 95.67\% dengan perolehan MSSE $1.51 \mathrm{x}$ 10-4, 4.42 x 10-4dan 1.32 x 10-4 (Tabel 3).

Tabel 3. MSSE dan Akurasi Pengujian.

\begin{tabular}{lllll}
\hline \multirow{2}{*}{ Lokasi } & \multicolumn{2}{l}{ Model Prediksi 6 Jam Ke Depan } & Model Prediksi 12 Jam Ke Depan \\
\cline { 2 - 5 } & MSSE & Akurasi(\%) & MSSE & Akurasi(\%) \\
\hline Lokasi \#1 & $1.62 \times 10^{-4}$ & 96.22 & $2.20 \times 10^{-4}$ & 88.96 \\
Lokasi \#2 & $4.46 \times 10^{-5}$ & 97.08 & $1.51 \times 10^{-4}$ & 92.47 \\
Lokasi \#3 & $1.59 \times 10^{-3}$ & 93.74 & $4.42 \times 10^{-4}$ & 92.29 \\
Lokasi \#4 & $2.11 \times 10^{-4}$ & 95.80 & $1.32 \times 10^{-4}$ & 95.67 \\
Rata-rata & & 95.71 & & 92.35 \\
\hline
\end{tabular}

Kedua model tersebut memiliki tingkat akurasi pengujian rata-rata di atas $90 \%$ yang menunjukkan bahwa model prediksi yang dibangun berunjuk kerja baik.

\section{KESIMPULAN DAN SARAN}

Pemanfaatan jaringan saraf tiruan untuk model prediksi deret waktu pasang surut air laut untuk 4 data set pada lokasi yang berbeda telah diujicobakan. Model prediksi menggunakan data pasang surut 7 hari sebelumnya untuk memprediksi pasang surut 6 jam dan 12 jam ke depan menghasilkan unjuk kerja prediksi yang memuaskan. Hal ini tampak dengan perolehan nilai MSSE pengujian yang rendah dan tingkat akurasi yang tinggi antara target dengan hasil prediksi

Kajian lanjutan yang disarankan adalah dengan mengembangkan struktur model jaringan saraf tiruan yang meliliki masukan dan target prediksi yang lebih panjang serta penggunaan data observasi untuk dapat membuat model prediksi yang akurat.

\section{DAFTAR PUSTAKA}

B.L. Meenaa , Dr. J.D. Agrawalb. (2015) 'Tidal Level Forcasting Using ANN', 8th International Conference on Asian and Pacific Coasts 2015, doi: 10.1016/j.proeng.2015.08.332

C hakraborty K ., Melhotra K ., Mohan C .K ., and R anka S . (1992) 'Forecasting the behaviour of multivariate time series using neural network', Neural Networks 5(6)961-970.

Rasel, Uddin, and Haroon. (2018) 'Application of DNN for Predicting River Tide Level', 2nd Int. Conf. on Innovations in Science, Engineering and Technology (ICISET), Chittagong, Bangladesh

S. Hayman, "The McCulloch-Pitts model," in IJCNN'99. International Joint Conference on Neural Networks. Proceedings (Cat. No.99CH36339), 1999, vol. 6, pp. 44384439 vol.6.

Wang, Yuan, and Tan.(2015) 'Application of BP Neural Network in Monitoring of Ocean Tide Level', International Conference on Computational Intelligence and Communication Networks 2015, doi:10.1109/CICN.2015.238 
Widaryanto and Kusumoputro, "Modeling and Designing Direct Inverse Control Using Back-propagation Neural Network for Skid Steering Boat Model," 2019 IEEE International Conference on Innovative Research and Development (ICIRD), Jakarta, Indonesia, 2019, pp. 1-5, doi: 10.1109/ICIRD47319.2019.9074761.

Winter and Widrow, "MADALINE RULE II: a training algorithm for neural networks," in IEEE 1988 International Conference on Neural Networks, 1988, pp. 401-408 vol.1.

Yen, P-H, Jan, C-D, Lee, Y-P and Lee, H-F (1996) Application of Kalman filter to short-term tide level prediction, .J. Waterway, Port, Coastal and Ocean Engineering, ASCE, 122(5), pp 226- 231. 